\title{
The Effect of Land Use Changes on Desertification Hazard (Case Study: Maraveh Tappeh Region of Golestan Province, Iran)
}

\author{
Asghar Farajollahi ${ }^{1}$, Hamid Reza Asgari ${ }^{2}$, Majid Ownagh ${ }^{3}$, Mohammad Reza Mahboubi ${ }^{4}$ \& Abdolrasoul Salman \\ Mahini $^{5}$ \\ ${ }^{1} \mathrm{Ph}$. D. student, Combating Desertification, Gorgan University of Agricultural Science and Natural Resources, \\ Golestan, Iran \\ ${ }^{2}$ Assistant professor, Department of Arid Regions Management, Gorgan University of Agricultural Science and \\ Natural Resources, Golestan, Iran \\ ${ }^{3}$ Professor, Department of Arid Regions Management, Gorgan University of Agricultural Science and Natural \\ Resources, Golestan, Iran \\ ${ }^{4}$ Associate professor, Department of Agricultural Extension and Education, Gorgan University of Agricultural \\ Science and Natural Resources, Golestan, Iran \\ ${ }^{5}$ Associate professor, Department of the Environment, Gorgan University of Agricultural Science and Natural \\ Resources, Golestan, Iran \\ Correspondence: Hamid Reza Asgari, Assistant professor, Department of Arid Regions Management, Gorgan \\ University of Agricultural Science and Natural Resources, Golestan, Iran. Tel: 98-9360-568-695. E-mail: \\ Hras2010@gmail.com
}

Received: July 12, 2016

Accepted: July 23, 2016

Online Published: November 4, 2016

doi:10.5539/mas.v11n1p168

URL: http://dx.doi.org/10.5539/mas.v11n1p168

\begin{abstract}
Land degradation and desertification caused by land use change is mainly due to human activities in arid and semi-arid and affect on the sustainable use of lands. The aim of this study was to evaluate the effects of land use changes on the desertification hazard in Maraveh Tappeh region. In this research, land use maps of 1986, 2000 and 2014 is provided using images of MSS, ETM and OLI sensors of Landsat satellite and land use map of 2024 is predicted using Markov chain model. According to the results, dense forest area is decreased during study period and with passing time, the area of agricultural land has increased. The results for the time interval of 2014-2028, showed it is possible that will be decreased semi-dense forest and dense rangelands and will be increased other land-use areas according to results of model predictions. In the study years, desertification maps were prepared using ESAs method and with the assumption of fixed all factors other than land use factor. The results showed that there was a lack of desertification as a class in 1986, but this class has been removed in other study years and has been added the area of this class into other classes. The compare of desertification hazard classes and theirs percentage of area in studied time periods showed that critical (C3) and fragile (F3) classes had increasing trend, clearly. The difference between classes since 1986 to 2000 is clearer and more specific and destruction seem clearer.
\end{abstract}

Keywords: desertification, ESAs method, hazard class, land use change, Maraveh Tappeh

\section{Introduction}

Land use is defined as use and management of land cover under human use and can be defined human intervention in the style of a certain type of land cover to produce, change or preservation of land (Orekan, 2007). Common patterns of land use are changed often as a result of human activity in different temporal and spatial scales. Desertification in arid, semi-arid, and dry sub-humid regions, is a global environmental problem. (Yang et al., 2005). Desertification sensitivity can be defined, in this context, as the response of the environment or part of it to a change in one or more external factors (Smelser \& Baltes, 2001). The UN (United Nation) Food and Agriculture Organization (FAO), has announced the agricultural sector causes one-third of global warming and climate change which the result of improper management and land use change (Lal, 2005). Sustainable use of land is under threat due to land degradation in arid and semi-arid that is mostly caused by human activity (Dumanski \& Pieri, 2000). Nassauer et al. (1999) and Bartel (2000) indicated that landscape pattern and function 
are closely related. Analysis of land use change is effective in baseline establishing and is helpful for monitoring the possible future changes (Zhang et al., 2015). Ernani and Gabriels (2006) evaluated land use changes in Ardakan of Iran using satellite image and reported that rainfed and irrigated agriculture have increased from 1976 to 2002. Authors notified that these changes of land use resulted in salinization and land degradation. Masoudi and Jokar (2015) investigated land-use planning using a quantitative model and GIS in Shiraz Township of. Prioritization of land-uses considering the ecological and socio-economic characteristics of the study area was performed. The results of this study showed that the maximum and minimum area of proposed use was $39.30 \%$ and $3.3 \%$ related to range and dry farming and irrigation agriculture with range, respectively. Bouabid et al. (2010) assessed desertification in Morocco's Souss river basin by means of MEDALUS with some modifications. Four main indicators including soil, vegetation, climate and management were used for the preparation of desertification sensitivity map. As given by the results, a large part of the area (72\%) was highly vulnerable to desertification. The southern part of the state has a critical and fragile condition with weather as the crucial parameter which is per se exacerbated by the physical and human factors. Hosseini at al (2012) studied desertification hazard using modified MEDALUS model in Niatak region of Sistan and indicated that of the whole studied region (comprising 4819.6 acres), 55\% are located in medium desertification intensity class, $26.34 \%$ in severe desertification intensity class, and $18.64 \%$ in vary severe desertification intensity class. However, these studies mainly focus on the analysis of land use changes or desertification, and an integrated evaluation of landscape change and its effects on desertification is rare. The objectives of this study are to (i) monitor and analyze the land use changes, (ii) predicting land use change in future in relation to previous changes and (iii) focus especially on land degradation or desertification as a result of such changes.

\section{Materials and Methods}

\subsection{Description of Study Area}

The study area was chosen in semiarid region of Maraveh Tappeh in Golestan province of Iran. The area is 120900 hectares with elevation ranging from $140 \mathrm{~m}$ to $1360 \mathrm{~m}$. The mean of precipitation is $355.6 \mathrm{~mm} / \mathrm{year}$ that maximum and minimum precipitation occurs in February and July, respectively. The mean of annual temperature is $18^{\circ} \mathrm{C}$ (Iranian weather organization, 2016).

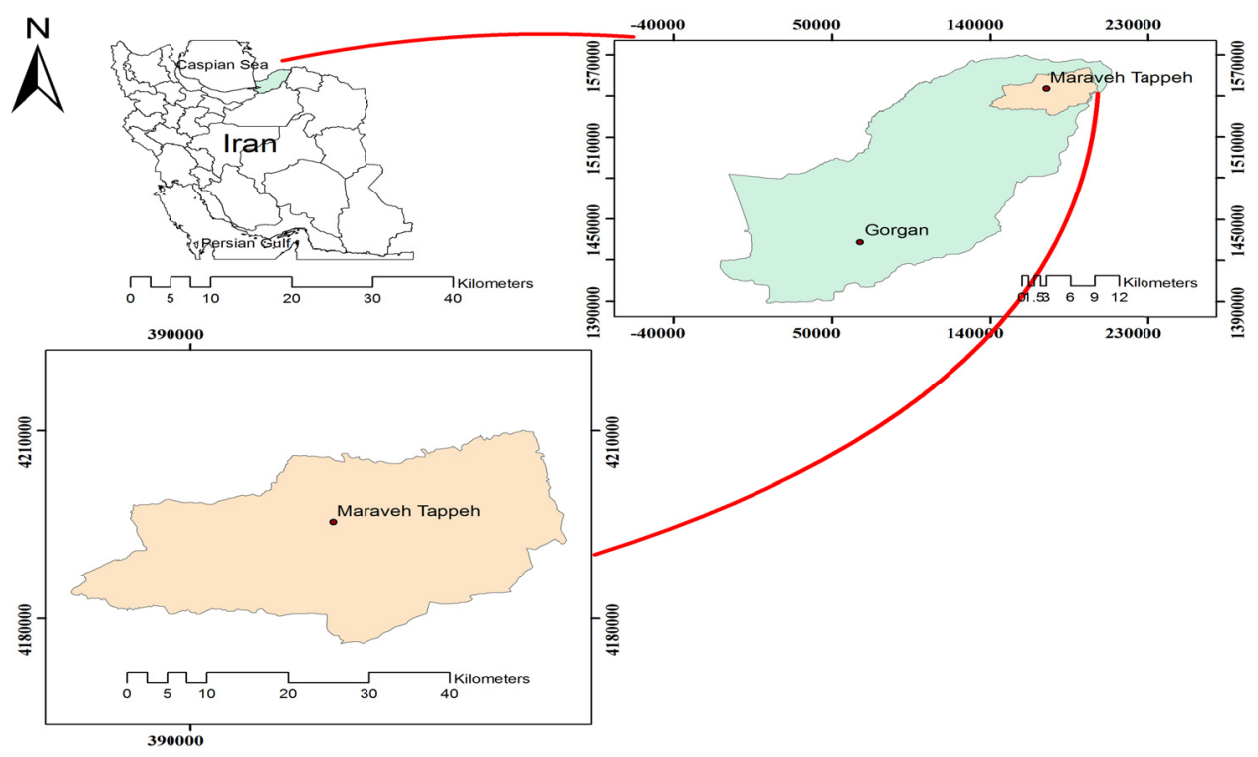

Figure1. Location of the case study area in Golestan province, Iran

\subsection{Methodology}

\subsubsection{Analyze and Monitoring Land Use}

Preparing land use map of 1986, 2000 and 2014 was performed via remote sensing and by Landsat satellite images. The dates, sensors, rows and passes of images are presented in Table 1. 
Table 1. Properties of used satellite images in this study

\begin{tabular}{lllll}
\hline Date & satellite & Sensor & Row & Path \\
\hline 19-May-1986 & Landsat 5 & MSS & 34 & 162 \\
02-June-2000 & Landsat 7 & ETM & 34 & 162 \\
16-May-2014 & Landsat 8 & OLI & 34 & 162 \\
\hline
\end{tabular}

Geometric correction of satellite images were performed by ground control points. Average error for geometric correction was achieved 0.735 pixel that is acceptable. In this study, histogram equalization of spectral values method was used for image enhancement. In order to identify the land uses, the supervised classification was used. Visual interpretation of existing data based on self-recognition and using Google Earth software also used in order to producing proper land use maps. Land use map of 2024 is predicted using Markov chain model that performed by Markov chain command in Idrisi Selva. Map classes of 2024 were carried out based on achieving land use maps from fuzzy classification in 2000 and 2014. In Markov model, land use map of 2000 and 2014 were introduced as the old and new maps, respectively.

\subsubsection{Assessment and Mapping of Desertification Hazard}

In this study, ESAs method was used for evaluating desertification hazard in the studied period. It is proper model for mapping desertification with regards to purpose of the study and sensitivity of model to land use change. Model parameters were initially revised according to the condition of study area as well as literature review. Then by relying on Geographic Information System, the evaluation and mapping of desertification was performed in studied years. All required data in the model were collected using previous studies or sampling and ultimately entered the Geographic Information System and its algorithms for calculating indices. Finally, sensitivity map of the area to desertification was prepared using these indicators. For mapping desertification hazard of Maraveh Tappeh region in 2014, was used data and information derived from field visits and laboratory analysis and for mapping desertification in other studied years, data of desertification map 2014 (representative of the current desertification hazard) was used with the assumption of fixed all parameters other than land use parameter. Each index is calculated from the geometric mean of its layers according to the following formula (Kosmas et al., 1999)

Index $(\mathrm{x})=\left\{(\right.$ layer1 $)(\text { layer2) } \ldots . . .(\text { Layer } \mathrm{n})\}^{1 / \mathrm{n}}$

Index (x): Desired index

$\mathrm{n}$ : the number of layers on each indices

The vegetation quality index (VQI) is assessing as the product of the above vegetation characteristics related to sensitivity to desertification using the following algorithm.

$\mathrm{VQI}=($ fire risk $*$ erosion protection $*$ drought resistance $*$ vegetation cover $){ }^{1 / 4}$

Climate quality index (CQI) is assessed using the following algorithm.

$\mathrm{CQI}=($ rainfall $*$ aridity $*$ aspect $){ }^{1 / 3}$

Soil quality indicators (SQI) for mapping ESAs can be assessed by following algorithm.

SQI $=($ texture $*$ parent material $*$ rock fragment $*$ depth $*$ slope $*$ drainage* organic matter $){ }^{1 / 7}$

The management quality index (MQI) is assessed as the product of land use intensity and the enforcement of policy for environmental protection using the following algorithm.

$\mathrm{MQI}=(\text { land use type } * \text { policy enforcement* population pressure })^{1 / 3}$

Each layer in relation to their impact on desertification received weighing between 1 and 2 that weight 1 and 2 was defined as best quality or no impact on desertification and worst quality or most effective in desertification, respectively.

Finally, Desertification Map (DM) is calculated based on this formula.

$$
\mathrm{DM}=(\mathrm{VQI} * \mathrm{SQI} * \mathrm{CQI} * \mathrm{MQI})^{1 / 4}
$$

Desertification status in the final map of desertification is divided into 8 subtypes according to Table 2. 
Table 2. The frequency distribution of intensity classes of desertification status (ESAs)

\begin{tabular}{llc}
\hline Type & Subtype & Range of ESAI \\
\hline Non affected & $\mathrm{N}$ & $1.16 \leq$ \\
Potential & $\mathrm{P}$ & $1.17-1.22$ \\
Fragile & $\mathrm{F} 1$ & $1.23-1.26$ \\
Fragile & $\mathrm{F} 2$ & $1.27-1.32$ \\
Fragile & $\mathrm{F} 3$ & $1.33-1.37$ \\
Critical & $\mathrm{C} 1$ & $1.38-1.41$ \\
Critical & $\mathrm{C} 2$ & $1.42-1.53$ \\
Critical & $\mathrm{C} 3$ & $1.54 \geq$ \\
\hline
\end{tabular}

\section{Results}

\subsection{Quantification and Classification of Land Use Changes}

The overall accuracy and Kappa index for used images is presented in Table 3 that has been achieved more than 80 for all cases and all studied years. These results are indicating high accuracy (above 60\%) and reliability of prepared maps.

Table 3. Overall accuracy and Kappa index for used images

\begin{tabular}{cll}
\hline \multirow{2}{*}{ Year } & \multicolumn{2}{l}{ Prepared land use map } \\
\cline { 2 - 3 } & Overall accuracy & Kappa index \\
\hline 1986 & 86.35 & 80.93 \\
2000 & 89.87 & 86.01 \\
2014 & 94.52 & 93.31 \\
\hline
\end{tabular}

Land use maps for 1986, 2000 and 2014 were prepared using satellite images and field observations that are presented in figures 1 to 3 . The area of land-use classes for the different studied years has been shown in Table 4 . In all years, low-density rangeland has largest proportion. With approaching the end of the study period, percent of area in agricultural land increased Table 4.

Table 4. The Area of Land Use Classes in Studied Years

\begin{tabular}{lllllll}
\hline \multirow{2}{*}{ Land use type } & 1986 & \multicolumn{3}{l}{2000} & & 2014 \\
& Area (ha) & percent & Area (ha) & percent & Area (ha) & percent \\
\hline Agriculture & 7466.85 & 6.18 & 9055.16 & 7.49 & 10332.97 & 8.55 \\
Dense rangeland & 12432.79 & 10.28 & 11366.77 & 9.40 & 11513.01 & 9.52 \\
Low-density rangeland & 94932.14 & 78.52 & 96330.31 & 79.68 & 96182.63 & 79.55 \\
Dense forest & 4120.37 & 3.41 & 1277.26 & 1.06 & 234.68 & 0.20 \\
Low-density forest & 1273.87 & 1.05 & 1620.84 & 1.33 & 1213.43 & 1 \\
Residential areas & 43.97 & 0.04 & 390.24 & 0.32 & 510.24 & 0.42 \\
River & 630.13 & 0.52 & 870.22 & 0.72 & 913.89 & 0.76 \\
\hline
\end{tabular}

Land use map 1986, 2000 and 2014 is presented in figures 1 to 3 that change trend of the amount of land use area from 1986 to 2014 is quite clear. 


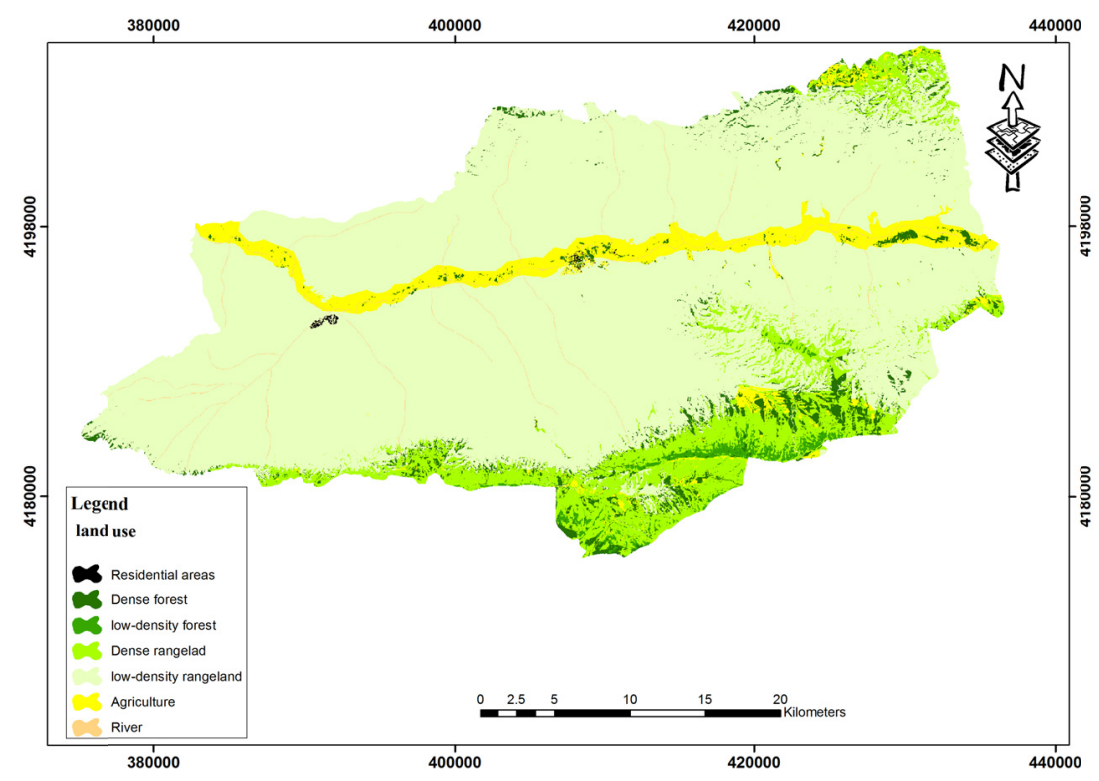

Figure 2. Land use map of 1986 in Maraveh Tappeh region

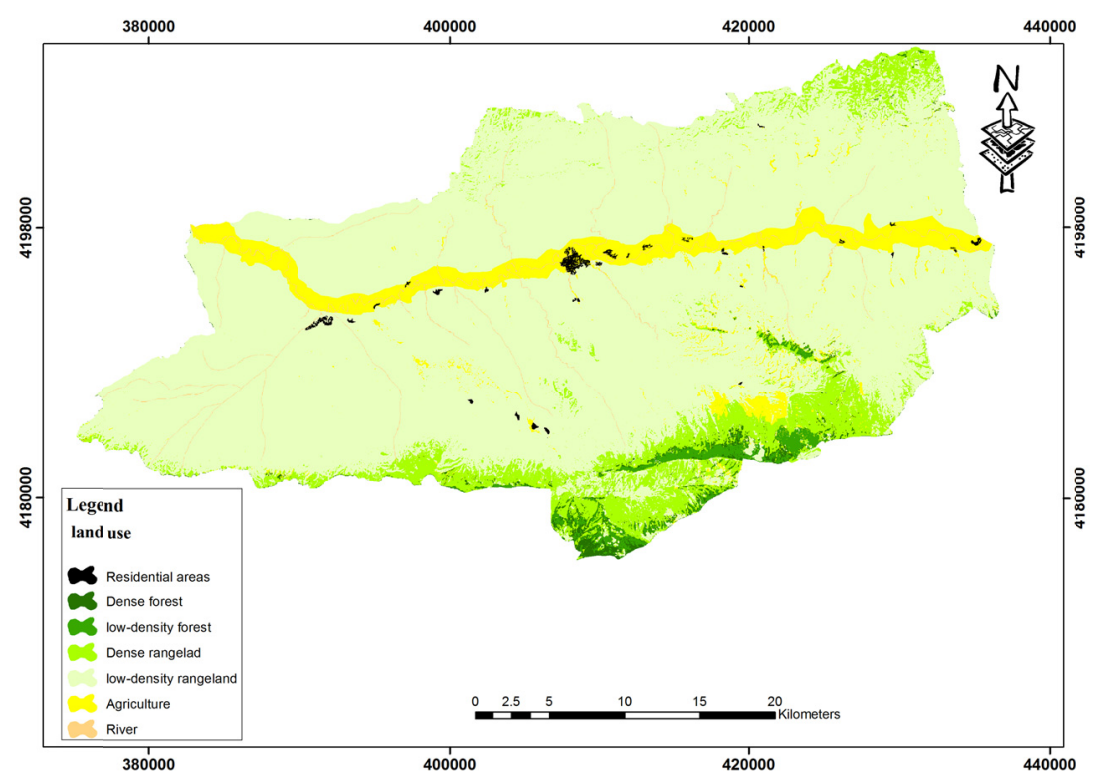

Figure 3. Land use map of 2000 in Maraveh Tappeh region 


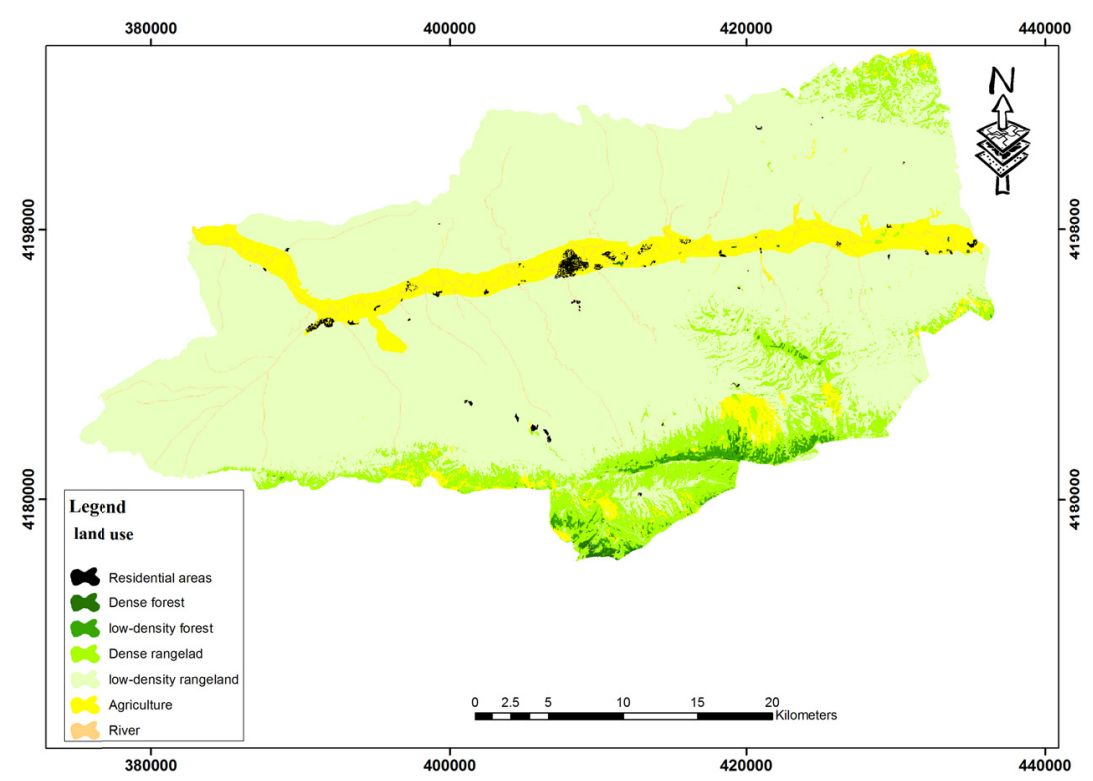

Figure 4. Land use map of 2014 in Maraveh Tappeh region

The results of prediction in 2028 showed a decrease of dense rangeland equal to 578.64 ha compare to the year 2014 a rate of 41.33 ha per year. During the period 2014-2028, the area of low-density forest and dense rangelands decrease and the area of the other land use types increased according to the results of prediction model. The highest increase is related to agricultural lands that will be increased 25.89 hectare per year Table 5 .

Table 5. Area and percent of land use / land cover 2014 and 2028 and the annual rate of change in 2014-2028

\begin{tabular}{|c|c|c|c|c|c|c|}
\hline \multirow[b]{2}{*}{ Land use type } & \multicolumn{2}{|l|}{2014} & \multicolumn{2}{|c|}{2028 (prediction) } & \multicolumn{2}{|l|}{$2014-2028$} \\
\hline & Area (ha) & percent & Area (ha) & percent & $\begin{array}{l}\text { Change of area } \\
\text { (ha) }\end{array}$ & $\begin{array}{l}\text { annual rate } \\
\text { change }\end{array}$ \\
\hline Agriculture & 10332.97 & 8.55 & 10695.48 & 8.84 & 362.51 & 25.89 \\
\hline Dense rangeland & 11513.01 & 9.52 & 10934.38 & 9.05 & -578.64 & -41.33 \\
\hline $\begin{array}{l}\text { Low-density } \\
\text { rangeland }\end{array}$ & 96182.63 & 79.55 & 96299.89 & 79.66 & 117.26 & 8.38 \\
\hline Dense forest & 234.68 & 0.20 & 563.10 & 0.47 & 328.42 & 23.46 \\
\hline Low-density forest & 1213.43 & 1 & 818.245 & 0.68 & -395.19 & -28.23 \\
\hline Residential areas & 510.24 & 0.42 & 666.12 & 0.55 & 155.88 & 11.13 \\
\hline River & 913.89 & 0.76 & 923.20 & 0.76 & 9.31 & 0.66 \\
\hline
\end{tabular}




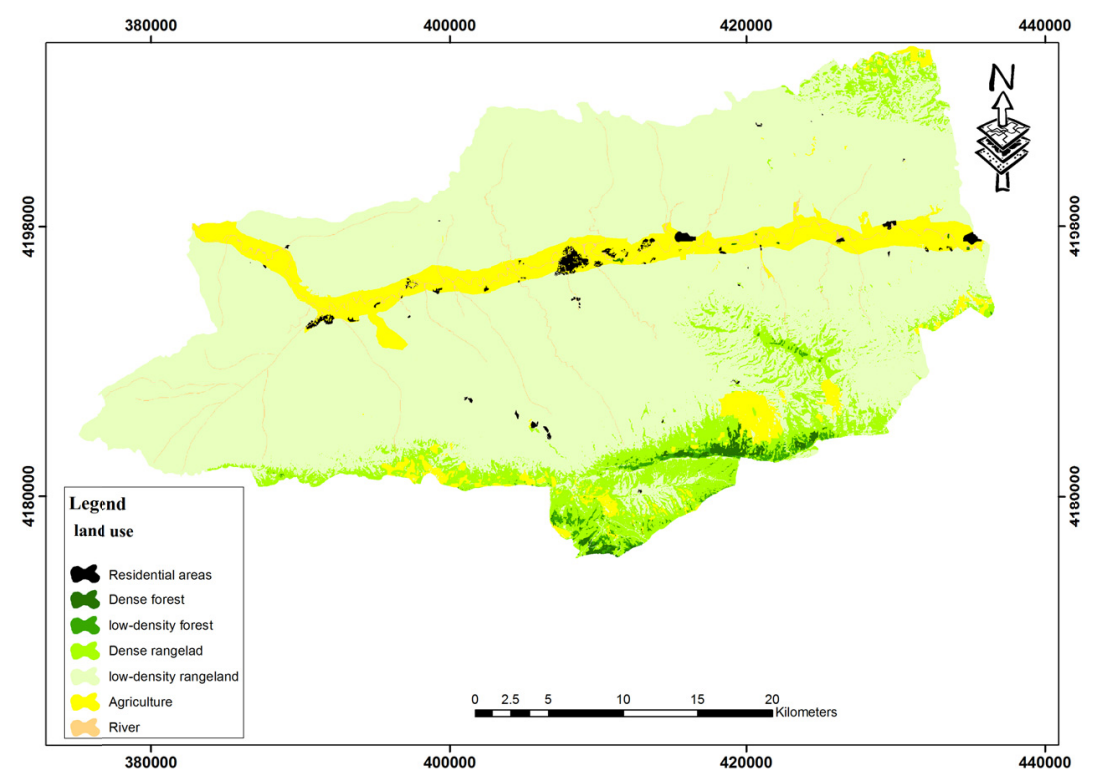

Figure 5. Land use predicting map for 2028 in Maraveh Tappeh region

\subsection{Analyze and Assessment of Desertification}

The results of analysis with ESAs model showed that vegetation cover is the dominant criteria in desertification hazard of Maraveh Tappeh region and its weighted average is 1.48. The lowest average value belongs to soil criterion Table 6.

Table 6. Value-Weighted Average for Studied Criteria in Maraveh Tappeh Region

\begin{tabular}{llll}
\hline Row & Criteria & value-weighted average & Desertification class \\
\hline 1 & Vegetation cover & 1.48 & Average \\
2 & Soil & 1.27 & Average \\
3 & Climate & 1.44 & Average \\
4 & Management (1986) & 1.35 & Average \\
5 & Management (2000) & 1.39 & Average \\
6 & Management (2014) & 1.41 & Average \\
7 & Management (2028) & 1.43 & Average \\
\hline
\end{tabular}

\subsubsection{Desertification Indices}

The weighted average values in desertification indices showed that gravel, aridity and land use type 2028 are the most effective factors with numerical values of $1.66,1.61$ and 1.6 respectively and three indicators including soil texture, slope and organic matter have the lowest impact on desertification of studied region with having 1.004, 1.17 and 1.19 , respectively.

\subsubsection{Desertification Intensity}

According to obtained results, value-weighted average is achieved 1.40 for current state of desertification intensity based on 4 studied criteria that by comparing this amount to the Table 2 , desertification intensity class is calculated critical (C1). This item for 1986, 2000 and 2028 is obtained 1.37 (F3), 1.39 (C1) and 1.41 (C1), respectively.

\subsubsection{The Frequency Distribution of Desertification Hazard Classes}

No- desertification was recognized in 1986, but it is removed in the other studied years and its area is added to other classes. The lowest number of desertification hazard classes is 6 hazard classes without Non Affected $(\mathrm{N})$ and Fragile (F1).

Comparison Chart of desertification hazard classes in the studied time periods and also the percentage of their 
area can be seen in figure 6. Over time, Critical (C3) and Fragile (F3) classes had been increased in term of area and land degradation is clear from 1986 to 2000.

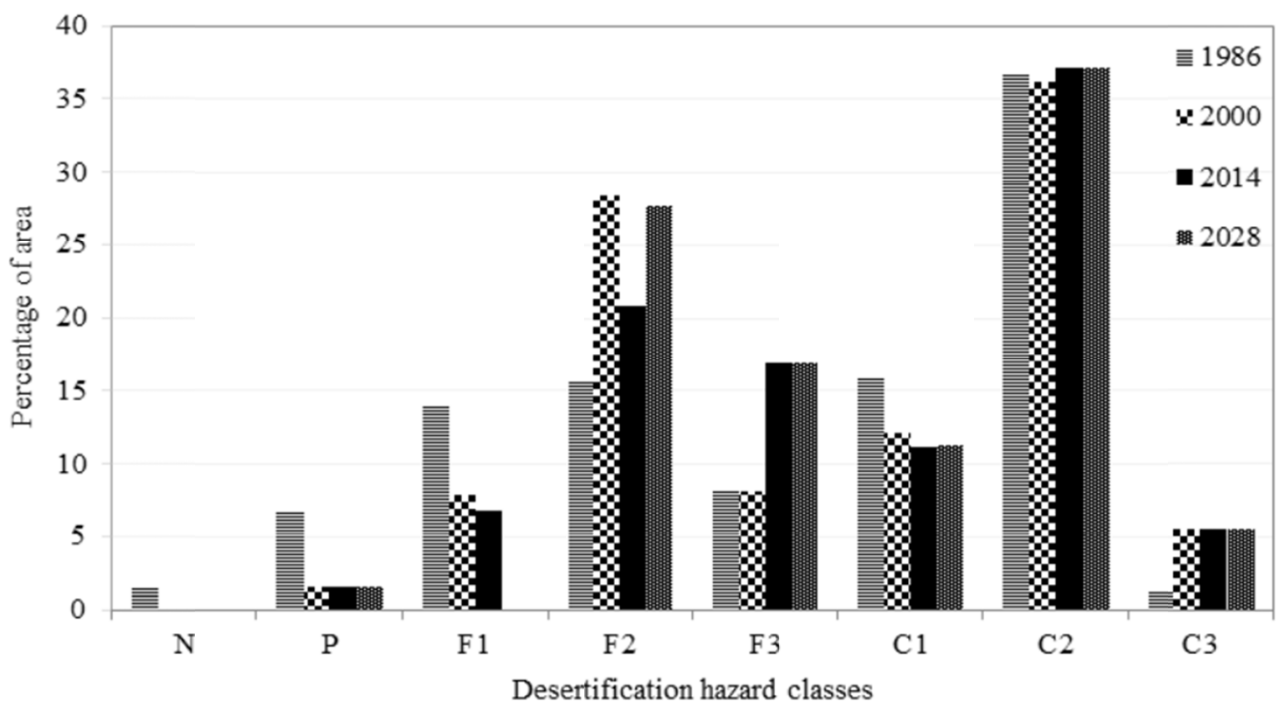

Figure 6. Comparison chart of frequency distribution of the hazard classes in studied years

The intensity map of desertification hazard during 1986 to 2028 is showed in figures 7 to 10 .

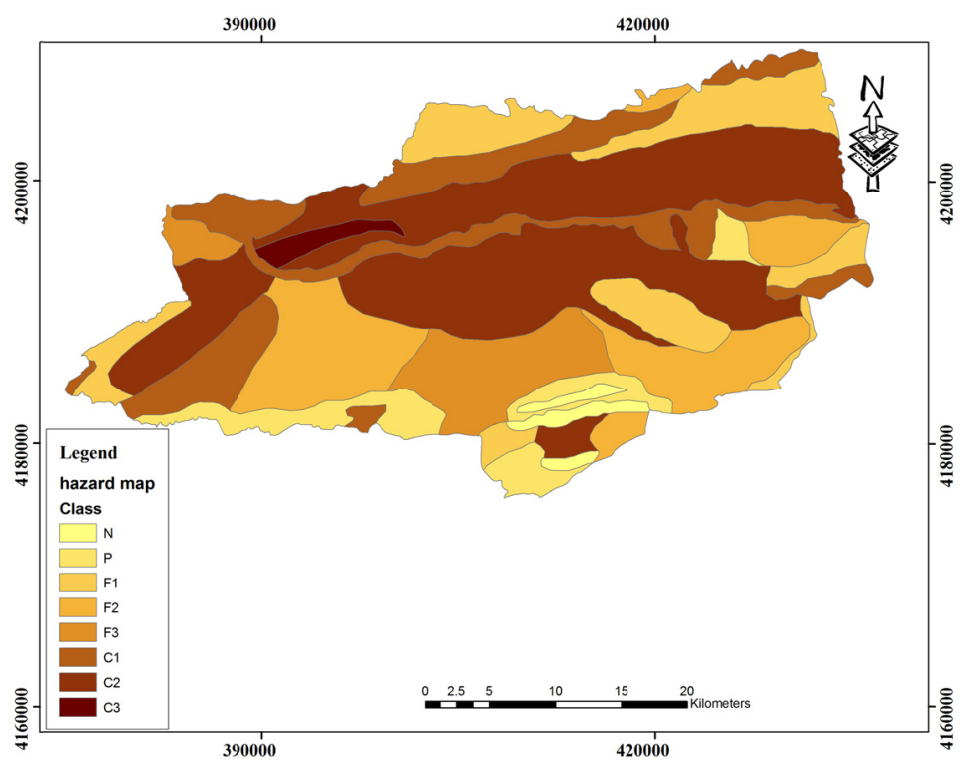

Figure 7. The severity map of desertification status in 1986 


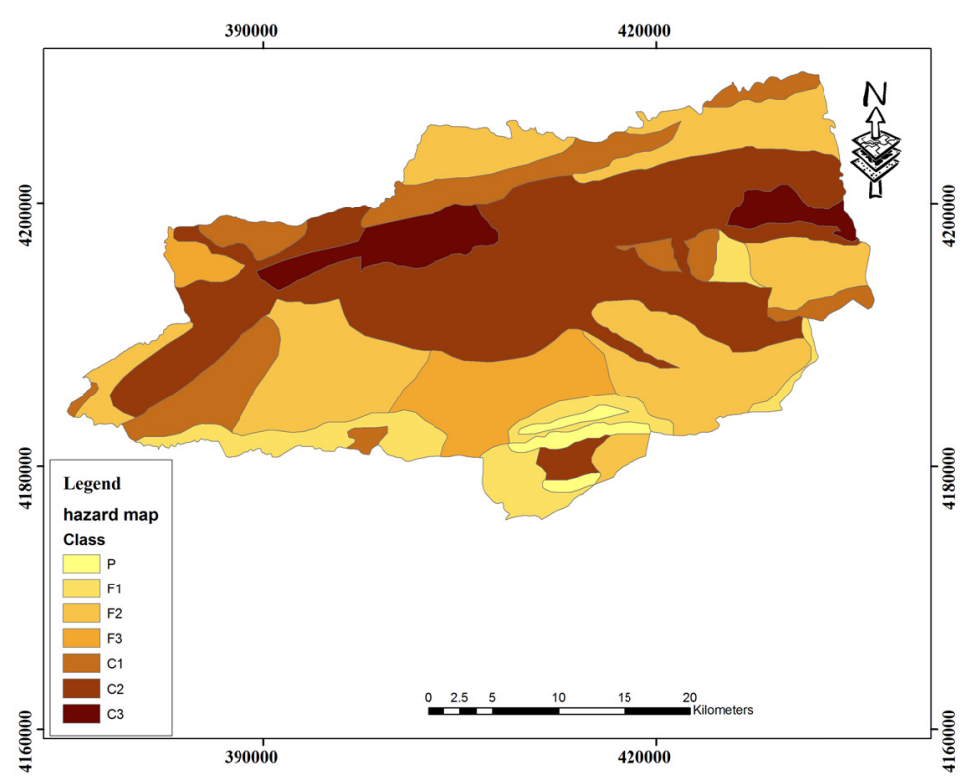

Figure 8 . The severity map of desertification status in 2000

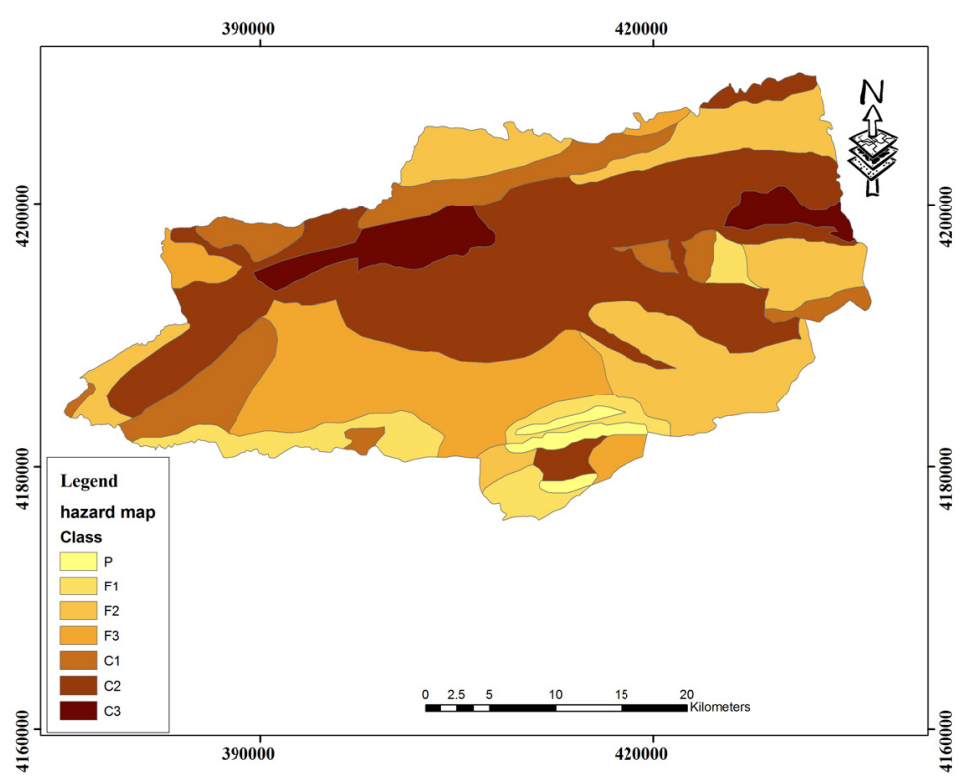

Figure 9. The severity map of desertification status in 2014 


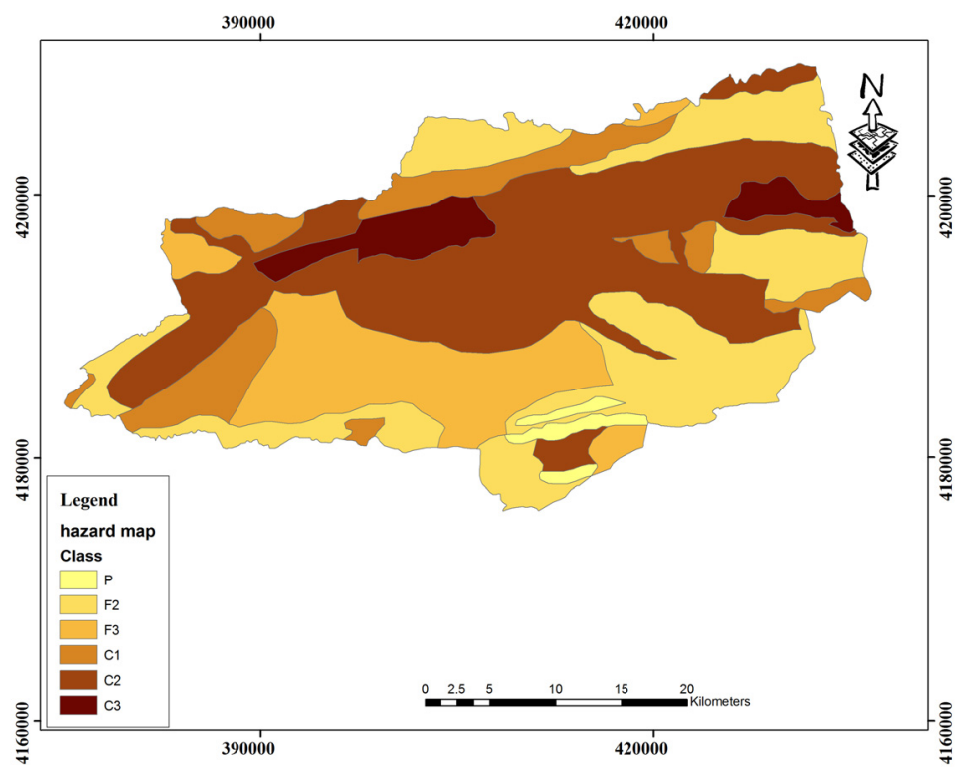

Figure 10. The severity map of desertification status in 2028

Changing the area of desertification hazard classes in studied period and the rate of the annual changes is presented in Table 7. The area of the fragile (F1) and critical (C1 \& C2) classes is decreased during three studied period, but F2 classes' area is decreased only in second period and is decreased in the other periods. Non affected class is existed in 1986-2000 with 139.33 ha annual decrease rate. The highest annual growth rate is occurred for the class of Fragile (F2) and during the period 1986-2000 with increasing 1101.63 ha per year and the highest annual rate of reduction is existed for the Fragile (F2) class and during the period 2001-2014 with 649.79 ha /year decreasing Table 7.

Table 7. The change of the area and the rate of annual change in the studied period for desertification hazard classes

\begin{tabular}{llllllll}
\hline $\begin{array}{l}\text { Qualitative } \\
\text { classification of } \\
\text { the severity of } \\
\text { desertification }\end{array}$ & $\begin{array}{l}\text { Change of } \\
\text { area (ha) }\end{array}$ & $\begin{array}{l}\text { Annual rate } \\
\text { of } \\
\text { (ha) }\end{array}$ & $\begin{array}{l}\text { Change } \\
\text { change }\end{array}$ & area (ha) & $\begin{array}{l}\text { of } 2015-2028 \\
\text { Annual rate } \\
\text { of change } \\
\text { (ha) }\end{array}$ & $\begin{array}{l}\text { Change of } \\
\text { area (ha) }\end{array}$ & $\begin{array}{l}\text { Annual rate of } \\
\text { change (ha) }\end{array}$ \\
\hline $\mathrm{N}$ & -1950.63 & -139.33 & 0 & 0 & 0 & 0 \\
$\mathrm{P}$ & -6271.35 & -447.95 & 0 & 0 & 0 & 0 \\
F1 & -7200.82 & -514.34 & -1388.18 & -99.16 & -8221.98 & -587.28 \\
F2 & 15442.80 & 1101.63 & -9097.09 & -649.79 & 8221.98 & 587.28 \\
F3 & 0 & 0 & 10485.27 & 748.95 & 0 & 0 \\
C1 & -4687.88 & -334.85 & -1078.12 & -77.01 & 0 & 0 \\
C2 & -522.06 & -37.29 & -1078.12 & -77.01 & 0 & 0 \\
C3 & 5209.94 & 372.14 & 0 & 0 & 0 & 0 \\
\hline
\end{tabular}

*: The negative values are indicating decrease in the area of the desertification class.

\section{Discussion and Conclusion}

A major part of the Iran is susceptible to desertification. Although the government has introduced many projects to combat desertification in recent years, it seems that they are not adequate due to the country's extensive arid region. This problem needs more attention and effective cooperation in the national as well as the international arena or level over the long term (Khosravi et al., 2014). The results of land use comparison during 28 years (1986-2014) showed that the highest amount of changes with regard to allocated percentage of the area for each land use is related to dense forest that is reduced considerably. Agriculture lands are located after dense forest in terms of changes and always have been rising in studied region. Ernani and Gabriels (2006) Stated that the area 
of agricultural lands has increased during 1976 to 2002 in Ardakan of Iran that is consistent with these results. Dewan and Yamaguchi (2009) in the study of land use changes (1975-2003) in Dhaka of Bangladesh reported that many constructions were carried out in the study period, as well as a significant decrease in the amount of water, arable land and vegetation cover due to increased urbanization, population growth and economic development. In this study also, forest and rangeland degradation reduced, change and conversion of these land uses area into other land uses are evident that is consistent with the results of Parabaharan et al. (2010) and Zhang et al. (2015). The results showed that vegetation cover is dominant criterion in desertification of Maraveh Tappeh. Vegetation cover affects on status and severity of wind and water erosion directly, this means that with creating roughness on the soil surface, prevent from direct collision of wind and rain into soil surface. In this study vegetation cover is the dominant criterion that is consistent with the results of Sepehr et al. (2007). Giordano et al. (2003) with MEDALUS model illustrated that climate is the most important indicator in desertification of Cicily region of Italy. According to obtained results, weighted average was achieved 1.40 for current state of desertification intensity based on studied criteria that by comparing this amount to the ESAs table, desertification hazard class is calculated critical (C1). This class is calculated F3 for 1986 and C1 fro other studied years. With the passage of time, desertification intensity class increased from middle and weak classes to the severe and very severe classes. In 1986, non-affected is existed as a class but is removed during other years and the area of this class is added to other classes. With moving from 1986 to 2028, the area of theF1, C1 and C2 are decreased and the area of $\mathrm{F} 3$ and $\mathrm{C} 3$ classes are increased and land degradation is more evident over time.

According to the results, increase of the desertification intensity and trend is due to land use changes and is affected by human factors that is consistent with the results of Roder and Syrbe (2000), Huang and Siegert (2002) and Symeonakis et al. (2007). In confirmation of these findings, Li et al. (2009) indicated that Lake QINGHAI watershed is sensitive to climate change and human challenge and land degradation process is rising in the study period (1997-2004) and illustrated that effective factors on desertification are human activities such as population growth, overgrazing of livestock and wrong policy making in the exploitation of resources. Incorrect policy of resource management such as intensive grazing and over-exploitation of land and water resources and deforestation are the main factors in the destruction of resources and the development of desertification process (Abahussain et al., 2002). The results of Salvati et al. (2013) in Basilicata, Italy showed that region with stable pattern of land-use are lower at risk of desertification than region with land use changes.

Desertification map of studied periods are indicating the change of hazard classes and increase of hazard intensity with the passing of time and these changes are representative the effects of land use changes on desertification hazard. These increase the intensity and class of hazard from 1986 to 2028 represents non-normative and out of the principles of sustainable development management and lack of attention to natural resources capacity. The results of this study can be used in future management for achieving sustainable development, so that the valuable ecosystems and resources in arid and semi-arid regions will be protected. The results of this study indicated wide degradation of natural resources especially in mountain area of this region has been occurred due to intensity of land use changes which indicates the need for paying more attention to these changes by administrative organizations and experts. Also by doing land use planning actions can be controlled land use changes and desertification hazard.

\section{References}

Abahussain, A. A., Abdu, A. S., Al-Zubari, W. K., El-Deen, N. A., \& Abdul-Raheem, M. (2002). Desertification in the Arab Region: Analysis of current status and trends. Journal of Arid Environments, 51(4), 521-545.

Bartel, A. (2000). Analysis of landscape pattern: towards a 'top down' indicator for evaluation of landscape. Ecological Modeling, 13, 87-94. http://dx.doi.org/10.1016/S0304-3800(00)00214-3

Bouabid, R., Rouchdi, M., Badraoui, M., Diab, A., \& Louafi, S. (2010). Assessment of land Desertification Based on the MEDALUS approach and elaboration of an action plan: The case study of the Souss River basin, Morocco, In Land Degradation and Desertification: Assessment, Mitigation and Remediation (pp. 131-145). Springer Netherlands. http://dx.doi.org/10.1007/978-90-481-8657-0-10

Dewan A. M., \& Yamaguchi, Y. (2009). Land use and land cover change in Greater Dhaka, Bangladesh: using remote sensing to promote sustainable urbanization. Journal of Applied Geography, 29, 390-401. http://dx.doi.org/10.1016/j.apgeog.2008.12.005

Dumanski, J., \& Pieri, C. (2000). Land quality indicators: research plan. Agriculture, Ecosystem \& Environment, 81, 93-102. http://dx.doi.org/10.1016/S0167-8809(00)00183-3

Ernani, M. Z., \& Gabriels, D. (2006). Detection of land cover changes using landsat MSS, TM, ETM+ sensors in 
Yazd-Ardakan basin, Iran. Proceedings of Agro Environment, 513-519.

Giordano, L., Giordano, F., Grauso, S., Iannetta, M., Sciortino, M., Rossi, L., \& Bonati, G. (2003). Identification of areas sensitive to desertification in Sicily Region. ENEA, Rome, Italy. 1-16.

Hosseini, S. M., Sadrafshari, S., \& Fayzolahpour, M. (2012). Desertification hazard zoning in Sistan region, Iran. Journal of Geographic Science, 22(5), 885-894. http://dx.doi.org/10.1007/s11442-012-0970-x

Huang, S., \& Siegert, F. (2002). Land cover classification optimized to desert areas at risk of desertification in North China based on SPOT VEGETATION imagery. Journal of Arid Environments, 67, 308-327.

Iranian Weather Organization (2016). Synoptic stations, Golestan province. Retrieved from http://www.irimo.ir/eng/index.php

Khosravi, H., Zehtabian, G. R., Ahmadi, H., \& Azarnivand, H (2014). Hazard assessment of desertification as a result of soil and water recourse degradation in Kashan region, Iran. Desert, 19-1, 45-55.

Kosmas, C., Kirkby, M., \& Geeson, N. (1999). European Commission The Medalus project- Mediterranean desertification and land use. Manual on key indicators of desertification and mapping environmentally sensitive areas to desertification, 87.

Lal, R. (2005). Soil erosion and carbon dynamics, Soil Tillage Research, 81(2), 137-142. http://dx.doi.org/10.1016/j.still.2004.09.002

Li, X. Y., Ma, Y. J., Xu, H.Y., Wang, J. H., \& Zhang, D. S. (2009). Impact of land use and land cover change on environment degradation in Lake QINGHAI watershed, northeast, Qinghaitibet plateau. Land Degradation and Development, 20, 69-83.

Masoudi, M., \& Joker, P. (2015). Land-use Planning using a Quantitative Model and Geographic Information System (GIS) in Shiraz Township, Iran. Ecopersia, 3(2), 959-974.

Nassauer J. I., Corry R. C., \&Cruse R. M. (1999). The landscape in 2025 alternative future landscape scenarios: a means to consider agricultural policy. Journal of Soil and Water Conservation, 57, 44-53.

Orekan, V. (2007). Implementation of the local land-use and land-cover change model CLUE-s for central Benin by using socio-economic and remote sensing data. Ph.D. thesis. Agonlin-Houegbo /Zagnanado. Republic of Benin.

Parabaharan, S., Srinivasa, R. K., Lakshumanan, C., \& Ramalingam, M. (2010). Remote sensing GIS application change detection study in coastal zone using Multi Temporal Satellite data. International Journal of Geomatics and Geoscience, 2,159-166.

Roder, M., \& Syrbe, R. (2000). Relationship between land use changes, soil degradation and landscape function. Landscape Ecology, 4, 235-246.

Salvati, L., De Angelis, A., Bajocco, S., Ferrara, A., \& Matteo, B. P. (2013). Desertification Risk, Long-Term Land-Use Changes and Environmental Resilience: A Case Study in Basilicata, Italy. Scottish Geographical Journal, 129(2), 85-99.

Smelser, N. J., \& Baltes, P. B. (Eds.). (2001). International encyclopedia of the social \& behavioral sciences, 11. Amsterdam: Elsevier.

Symeonakis, E., Calvo, -C. A., \& Arnau, -R. E. (2007). Land Use Change and Land degradation in Southeastern Mediterranean Spain. Environmental management, 40, 80-94. http://dx.doi.org/10.1007/s00267-004-0059-0

Yang, Z., Zhang, K., Jia, B., \& Ci, L. (2005). Desertification assessment in China: An overview. Journal of Arid Environments, 63, 517-531.

Zhang, F., Tiyip, T., Feng, Z. D., Kung, H. -T., Johnson, V. C., Ding, J. L., Tashpolat, N., Sawut, M., \& Gui, D. W. (2015). Spatio-temporal patterns of land use/cover changes over the past 20 years in the middle reaches of the Tarim River, Xinjiang, China. Land Degradation and Development, 26, 284-299. http://dx.doi.org/10.1002/ldr.2206

\section{Copyrights}

Copyright for this article is retained by the author(s), with first publication rights granted to the journal.

This is an open-access article distributed under the terms and conditions of the Creative Commons Attribution license (http://creativecommons.org/licenses/by/4.0/). 